\title{
The 'lived experiences' of the love of God according to a prayer in the letter of Ephesians
}

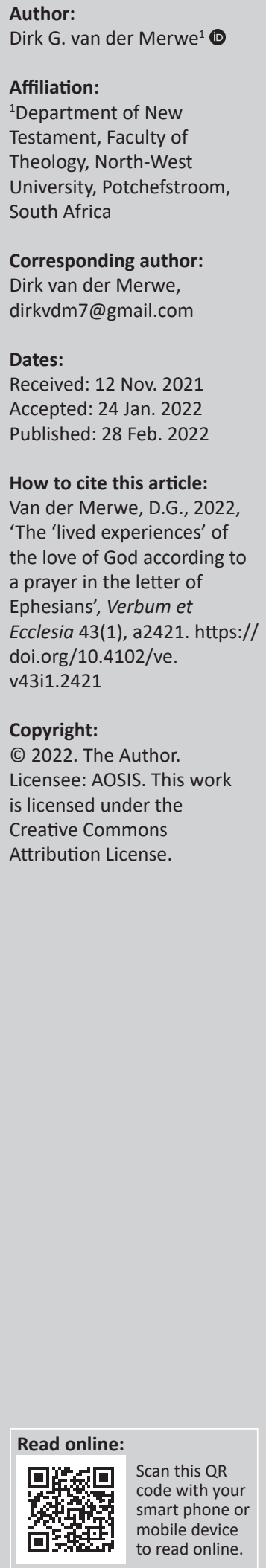

The epistle to the Ephesians is regarded as a circular letter, yet it also contains two specific intercessory prayers $(1: 15-23 ; 3: 14-21)$ in which the Trinity concept features persuasively. On the one side, this research tends to point out how the divine attribute of love relates to all three the divine persons in cooperation and how the trinity concept features in the prayer in Ephesians 3:14-21. On the other side, the article also aims to identify conceived spiritualities (lived experiences of the divine trinity) that the hearers (readers) could have perceived and experienced when hearing this prayer or even praying this prayer themselves. Methodologically, the 'hermeneutic research approach', as proposed and developed by Waaijman and Iser, has been deductively applied for the investigation in this research. Firstly, the dynamic and relational character of the trinitarian God is briefly discussed. Secondly, an exploration of the appearance and inclusion of trinitarianism in Ephesians has been conducted. Thirdly, the focus falls on trinitarian spirituality (the divine attribute of love) in Ephesians 3:14-21. Mechanisms proposed by Waaijman and Iser, which could foster spiritualities in the reading of texts, have been applied to Ephesians 3:14-21 to contribute towards a validation for a trinitarian spirituality of prayer.

Intradisciplinary and/or interdisciplinary implications: This research challenges believers to experience divine presence in the reading of biblical texts, how the reader can become involved in the text. This spirituality will certainly prepare them to experience the divine involvement in their personal life every day. The magnificent methodology proposed by Waaijman has been applied to guide the believers in accomplishing this.

Keywords: Ephesians; Trinity concept; lived experiences; intercessory prayers; love.

\section{Introduction}

Knowing something about who God is can be discovered through learning about the attributes ascribed to this divine being in the Bible. The more we know about the love attribute of God, the more the Christian believer's love can grow and mature. In Ephesians $3: 14-21$, we find an intercessory prayer $^{1}$ of the author for all those who would read (or hear) this letter in the different churches to which this letter would have been circulated. ${ }^{2}$ The essence of this prayer is about a trinitarian God revealing the love of this God to those who believe in this divine being.

To determine and comprehend the 'intention' for the author's teaching and actions in this passage, Ephesians 2:21-22 and 3:11-13, must be considered. The subject in both these passages is Jesus Christ and His eternal, central role in God's plan. The following phrases verify the claim of this subject: 'in whom' (2:21), 'in the Lord' (2:21), 'in him' (2:22), 'in Christ Jesus' (3:11), 'in whom' (3:12) and 'in him' (3:12). The mutual faith of Christian believers shares the centrality of Christ: 'begins with Jesus Christ, remains rooted in Him and comes back to Him' (Kroll 2007:40). For the author, his life revolved around Christ. This incites him to encourage the believing readers also to realise that everything in their lives should be founded on Christ. Equally, Jews and Gentiles could only access God through Christ. For that reason, live in Christ: bow before God and claim the indwelling of Christ, the empowerment of the Spirit, and a love-immersed life. All this was

1.Prayer plays an important part in the Bible, in both the Old and New Testaments. According to Carter (2014:1), there are "about 650 prayers listed and 450 recorded answers to prayer. Then, there are at least nine types of prayer listed in the Bible: prayer of faith (Ja 5:15), prayer of agreement (also known as corporate prayer) (Ac 2:42), prayer of request (also known as petition or supplication (Phlp prayer of intercession (1 Tm 2:1), prayer of imprecation (Ps 69) and praying in the Spirit (1 Cor 14:14-15)'. More types of prayer can be prayer of
added.

2.The opening phrase (Toútou xáplv, 'for this reason', 3:14) of the prayer, harks back to the use of the same phrase at the beginning of $3: 1$. Verses $3: 2-13$ is a parenthesis that the phrase points back to $2: 19-22$, which pertains to the discussion of God incorporating believing Gentiles alongside believing Jews into his people as the one 'new person' (cf. Lincoln 1990:201). 
indubitably a good enough reason for the author to promote Jesus Christ (Kroll 2007:40), to encounter the full indwelling and empowerment of God.

An analysis of this prayer in Ephesians 3:14-21 will show that God is glorified through revealing God's love in Jesus Christ. ${ }^{3}$ This occurs through the strengthening of a believer 'by the Spirit in the inner being' (3:16). This thesis can be verified through the multiple varieties of references to knowledge and nuances of revelation in the prayer. The revelation concept has already been introduced by the author in the previous pericope. ${ }^{4}$ Therefore, the dual objective of this article is on the one side, to point out how the divine attribute of love relates to all three the divine persons in cooperation and how the trinity concept features in the prayer in Ephesians 3:14-21. On the other side, the article also aims to identify conceived spiritualities (lived experiences of the divine trinity), which the hearers (readers) could have perceived and experienced when hearing this prayer or even praying this prayer themselves. This will show how the author in his prayer for the believers wants to convince them (by using superlative language and constructive rhetoric) ${ }^{5}$ that God is glorified in the unceasing experience of the divine revelation of the love of God through knowledge and faith in Jesus, as powerfully revealed by the Spirit in everyday life under all circumstances. ${ }^{6}$ This attributive of unceasing love of the trinity, then, finds an extension in the everyday 'lived experiences' of God's involvement in the lives of Christian believers.

The 'hermeneutic research approach', as proposed and developed by Waaijman and Iser, will be deductively applied to investigate this subject. Firstly, the dynamic and relational character of the trinitarian God will be briefly surveyed. Secondly, the occurrence and featuring of trinitarianism in Ephesians will be explored. Thirdly, the focus will fall on trinitarian spiritualities of the love of God in Ephesians 3:1421. Mechanisms proposed by Waaijman (2002) and Iser (1978), which could foster spiritualities in the reading of texts, will be applied to this focus on Ephesians 3:14-21 to contribute towards validation for a trinitarian spirituality in the author's prayer.

\section{The dynamic and relational character of the divine Trinity}

Jones (2002:89), in his discussion of Trinitarian spirituality, argues correctly that a 'trinitarian view of $\operatorname{God}^{7}$ indicates that 3.Love occurs 19 times in Ephesians

4.Already in the previous pericope (Eph 3:1-13), the author prepares the reader for the revelation of the trinity, as a 'lived experience' when praying: Ephesians 3:5,

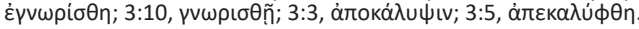

5.See subsections namely, 'First mechanism: The dynamic interaction between the text and the reader' and 'Fourth mechanism: Filling the gaps.'

6.See Ephesians 4-6.

7.The author of this article is very much aware of the still ongoing debate, whether the church can refer to God as a trinitarian God or not. The following authors are
God's first language is communion, self-expression and intimate presence'. According to him, communion forms the foundation of any kind of prayer. Communion prompts believers that they principally move towards experiencing the presence of God. The Trinity concept asserts that God and believers are meant to share in a relationship of intimacy and love. 'The Persons [in the trinity], too, exist in the category of Relation, the Doubling in the Relation of Identity' (Sonderegger 2020:519). '[T]he Persons in their Relations simply and properly sum and complete and rehearse all that is the Divine Life in Its Self-Offering and Consummation' (Sonderegger 2020:519).

This God is an active being, manifesting Godself in many ways. These ways relate to the needs, the challenges and demands of believers to experience communion with this God (Brümmer 2010:4). God is, therefore, a Being for those who believe that supreme happiness consists in enjoying a loving communion with the trinitarian God (cf. Brümmer 2005:31).

Barth, magnificently, years prior and in addition to Jones, describes how God exists in fellowship. According to him, the attitude and action of God consist of always seeking the creation of fellowship between Godself and humans (Barth 2009:18). Therefore, what God seeks and creates between Godself and humans is exactly according to the will of God and God's accomplishments. That God is God, resides in the fact that God loves 'and it is the expression of His [God's] loving that He [God] seeks and creates fellowship with us' (Barth 2009:19, 96; cf. also Poythress 2020:634). ${ }^{8}$ For Barth, the act of God's love is visible in God's revelation and speaks for itself. It is in God's acts in Jesus and in everyday involvement that this God seeks and generates communion with people.

Eberhard Jüngel (2002:265-275) argued that a 'correspondence' (Entsprechung) exists 'between the economic and immanent triunity, a correspondence, that is to say, between the way God is in self-being (in se) and the way God is for us (pro nobis)' (translated by Johnson 1997:45). Therefore, Brümmer's (2010:4) comments make sense that for the sake of (contemporary) Christian spirituality 'the ontological presuppositions of spirituality and the image of the God with whom [believers] seek fellowship in life, cannot be free from reappraisal and reinterpretation'. Hence, when believers pursue communion with God in their midst who surrounds them with God's love in continuously changing circumstances, then God cannot be an unchanging Being. This God is an active Being, manifesting Godself in many ways. These ways relate to the needs, the

only but a few of the plethora of publications, throughout history, about understanding God as a trinity: Sonderegger (2020); Poythress (2020); Holmes (2012); Emery, Levering and Cessario (2012); Phan (2011); Emery (2011); McCall (2012); Emery, Levering and Cessario (2012); Phan (2011); Emery (2011); McCall and Rea (2010); Dünzl (2007); Letham (2004). See also Venter (2015) for his approach in this essay God from a trinitarian/triune perspective.

8.Pyothress stresses the necessity of fellowship between God and believers. Without such fellowship believers will never understand the power and presence of God such fellowship believers will never understand the power and presence of God
during reasoning and analysis. See also Van der Merwe (2019) on 'Divine fellowship in the Gospel of John'. 
challenges and demands of these believers to experience communion with this God (Brümmer 2010:4). God is therefore a Being for those who believe that supreme happiness consists in enjoying the loving communion of the trinitarian God (Brümmer 2005:31).

\section{Trinitarian formulas in Ephesians}

According to the previous section, the God of the New Testament, then, is one perfect Being revealed in three persons: The Holy Spirit is idiosyncratic from the Father who designed the redemption process, carried out by the Son. The Son achieved this through his life, death, and resurrection. The position of the Holy Spirit is to apply that work now, every day.

God the Father is referred to in all the chapters in Ephesians. ${ }^{9}$ This occurs only in reference to God as Father, distinctive from the Son and Spirit. This is also apart from when the author uses the noun $\theta \varepsilon$ so $\varsigma$ to refer to the Father. It also excludes the pronouns (he, him, his). If the Father then is encompassed in all these references, then in chapter 1 the Father will be excluded from only four verses.

The reference to Jesus as Son of God is used only once in 4:13 while the title, Lord Jesus Christ, occurs 42 times. $^{10}$ The author uses this title more often than the title, Son of God. His objective was to point out the divine power of the God man, Jesus Christ. This also facilitates to differentiate between the Son and the Father. Again, all the pronouns referring to the Son are not counted.

The Holy Spirit as the Spirit of God has been referred to 11 times in Ephesians. ${ }^{11}$ Again, no pronouns are included. Additionally, to all the verses highlighting the distinctive Persons of the trinitarian God, 10 additional Triadic passages (see Table 1)

\begin{tabular}{|c|c|c|c|}
\hline Verse & Father & Son & Spirit \\
\hline $1: 3$ & $\begin{array}{l}\text { 'Blessed be the God and } \\
\text { Father' }\end{array}$ & $\begin{array}{l}\text { 'of our Lord Jesus } \\
\text { Christ' }\end{array}$ & $\begin{array}{l}\text { 'every spiritual } \\
\text { blessing'14 }\end{array}$ \\
\hline 1:11-13 & $\begin{array}{l}\text { 'Him who works all things } \\
\text { according to the counsel of } \\
\text { His will' }\end{array}$ & 'trusted in Christ' & $\begin{array}{l}\text { 'sealed with the Holy } \\
\text { Spirit of promise' }\end{array}$ \\
\hline 1:17 & 'God ... the Father of glory' & 'our Lord Jesus Christ' & $\begin{array}{l}\text { 'a spirit of wisdom } \\
\text { and revelation'15 }\end{array}$ \\
\hline 2:18 & 'access ... to the Father' & 'through him' & 'in one Spirit' \\
\hline 2:22 & 'a dwelling of God' & $\begin{array}{l}\text { 'in whom you also are } \\
\text { being built together' }\end{array}$ & 'in the Spirit' \\
\hline $3: 2-5$ & 'grace of God' & 'the mystery of Christ' & $\begin{array}{l}\text { 'revealed by the } \\
\text { Spirit' }\end{array}$ \\
\hline $3: 14-17$ & $\begin{array}{l}\text { 'I bow my knees before the } \\
\text { Father' }\end{array}$ & $\begin{array}{l}\text { 'so that Christ may } \\
\text { dwell in your hearts' }\end{array}$ & $\begin{array}{l}\text { 'with power through } \\
\text { his Spirit' }\end{array}$ \\
\hline $4: 4-6$ & 'one God and Father' & 'one Lord' & 'one Spirit' \\
\hline $5: 18-20$ & $\begin{array}{l}\text { 'always giving thanks ... to } \\
\text { God and Father' }\end{array}$ & $\begin{array}{l}\text { 'in the name of our } \\
\text { Lord Jesus Christ' }\end{array}$ & $\begin{array}{l}\text { 'be filled with the } \\
\text { Spirit' }\end{array}$ \\
\hline $\begin{array}{l}6: 10-11 \\
17\end{array}$ & $\begin{array}{l}\text { 'Put on the full armour of } \\
\text { God' }\end{array}$ & 'be strong in the Lord' & $\begin{array}{l}\text { 'the sword of the } \\
\text { Spirit' }\end{array}$ \\
\hline
\end{tabular}

9.Ephesians $1: 2,3,17 ; 2: 18 ; 3: 14 ; 4: 6 ; 5: 20 ; 6: 23$.

10.Ephesians ' $1: 1 \mathrm{ff}, 5,9,12,17,20 ; 2: 5 \mathrm{ff}, 10,12 \mathrm{f}, 20 ; 3: 1,4,6,8,11,17,19,21 ; 4: 12 \mathrm{f}$ $15,20,32 ; 5: 2,5,14,20 f, 23 \mathrm{ff}, 29,32 ; 6: 5 f, 23 f^{\prime}$ (Daniels 2014:1).

11.Ephesians 1:3 [implicitly], 13, 17 [implicitly]; 2:18, 22; 3:5, 16; 4:3f, 30; 5:18; 6:17f. occur. ${ }^{12}$ Table 1 points out how Ephesians is saturated with Trinitarian references according to the translations of the NKJV and NASB95. ${ }^{13}$ These passages refer to all three persons of the Trinity arranged and refer to in close and logically tight textual boundaries. In each they are clearly distinguished in Person and role, although pointed out clearly their unity in being and purpose (Daniels 2014:1).

\section{Trinitarian spirituality in a prayer to the Ephesians in 3:14-21 Defining spirituality}

Perrin (2007:31) was but only one who refers to the many diverse definitions of Christian spirituality. The definition, ${ }^{16}$ as proposed by Schneiders (2016), deems to be important and relevant for the approach and understanding of spirituality in this article. For her Christian spirituality is:

$[T]$ he lived experience of Christian faith, which is an ongoing project of life integration in the context of, in response to, and in terms of the revelation of God in Jesus Christ. (p. 417)

Her reference to 'lived experience of Christian faith' is interpreted in this article as a 'lived experience of the divine' in the divine-human relationship. The rest of her definition relates to 'living a life of transformation and self-transcendence that resonates with that of the divine-human relationship' (Van der Merwe 2014:373-374) ${ }^{17}$ and experience of the divine. Barton's definition (2006:10) of Christian spirituality resonates with that of Schneiders'. He interprets it as 'a sense of divine presence'. It 'has to do with the experience of that presence and living in the light of it' (Barton 2006:11).

Spirituality appears to be an extension of continuous divine revelation. It is the lived experiences of divine love every day in different nuances and situations. This is evident from the culmination in the author's prayer (3:14-21) that the readers ${ }^{18}$ may experience the love of God, 'to know the love of Christ, which surpasses knowledge, that you may be filled to all the fullness of God' (3:19). The revelation of God's love is not narrowly experienced only through acts of love. Through every form of divine intervention, the love of the trinitarian God is revealed and experienced, for the divine intervention is the result of divine love.

\footnotetext{
12.These Triadic passages occur in Ephesians $1: 3 ; 11-14,7 ; 2: 18,22 ; 3: 2-5 ; 14-19$ $4: 4-6 ; 5: 18-21 ; 6: 10-11,17$
}

13.New King James Version and New American Standard Bible: 1995 Update.

14.Fee (1994:666) called spiritual blessings 'Spirit blessings, blessings that pertain to the Spirit'.

15.'With the presence of revelation in the phrase as adapted here, the connection to God as source of wisdom is only strengthened. With or without an article, spirit is God's Spirit enlightening believers who are called to a messianic vocation' (Neufeld 2001:70).

16.See also Scheldrake (2000:40); Waaijman (2002:312); Perrin (2007:16-22) Brümmer (2010:2-5) and Kim (2017:25-35) for more nuanced definitions on Christian spirituality.

17.For Schneiders (1986:267), 'the experience should be affective, cognitive, social, personal, God centred and other directed all at the same time' (also see Brümmer 2010:1-5).

18. In this article, I will for comfortability refer to readers, also bearing in mind that most were hearers. 
This kind of interpretation is further verified in the statement 'to know the love of Christ' (3:19) to imply more than merely knowing cognitively about God's love. In this context, the verb know ( $\gamma v \tilde{\omega} v \alpha i)$ is often best translated as 'to experience'. Therefore, 'may you come to experience how he loves you' (Bratcher \& Nida 1993:88)

\section{The application of different mechanisms in the reading of the text to become aware of the spiritualities fostered by the text}

In his significant publication, Spirituality: Forms, Foundations, Methods, Kees Waaijman (2002:689) discussed four different methods of 'Spirituality Research'. The one relevant for this article is the 'hermeneutic research approach'. ${ }^{19}$ Complementary to the work of Waaijman is the publication of Wolfgang Iser (1978), The Act of Reading: A Theory of Aesthetic Response. This article will apply some of these mechanisms, which Waaijman discusses in his 'hermeneutic research approach', to the prayer in Ephesians 3.

\section{First mechanism: The dynamic interaction between the text and the reader}

Authors normally apply various figures of style and specific vocabulary 'to constitute different forms of speech to transport the reader into particular conceptual and experiential worlds' (Van der Merwe 2019:2). The following distinguished form of speech in Ephesians is to be investigated to determine 'how the reader is drawn into the text to experience' (Van der Merwe 2019:3) all three persons of the trinity, how they are involved in the reader's (hearer) experiencing of God's love every day. To accomplish this, the author used three iv $\alpha$ particles $(3: 16,18,19)$ to connect the reader with the trinitarian God. The intercessory prayer (3:14-19) is introduced in verses 14 and 15 and consists of three main requests to God (3:1619). The three wishes of the author become shorter and faster, culminating in the last one (3:19b), comprising only eight

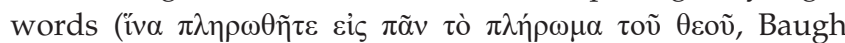
2016:269)

The development and culmination point of the prayer is to experience 'the fullness of God' (3:19) because of God's love for them. The first request is introduced with the phrase, ivo $\delta \tilde{\varphi}$ v $\mu$ ĩv ('that he might grant you'). What the hearers are to be granted with is 'to be strengthened with power through his Spirit in the inner being' (3:16). The second request, starting with iv $\alpha$, similarly asks for strengthening. In this case, the author uses the phrase 'iv $\alpha \dot{\varepsilon} \xi 1 \sigma \chi v$ $\sigma \eta \tau \varepsilon^{\prime}$ ('that you might be empowered', 3:18). This empowerment is for the hearers to grasp ( $\kappa \alpha \tau \alpha \lambda \alpha \beta \varepsilon \dot{\varepsilon} \sigma \theta \alpha)$ all the dimensions of love and 'to know ( $\gamma v \tilde{\tilde{\omega}} v \alpha \mathrm{l})$ the love of Christ, which surpasses knowledge'. Lincoln (1990:197) correctly observed that in the third ivo clause (3:19), the prayer has now reached 'rhetorical momentum', for the final request to become the culmination point of the prayer - 'that you might be filled up to all the fullness of God' (cf. Baugh 2016:268; Heil 2007:157; Lincoln 1990:197, 214; Bratcher \& Nida 1993:88; Roberts 1983:94).

\section{Second mechanism: Reading a text composes images}

Any reader's imagination composes images when a literary text is read. This was even more so at the time of the author when most of the people could neither read nor write. The images relate to the content of the text. It is the reader's choice to compose subjectively and selectively '... images out of the multifarious aspects of the text ${ }^{20}$ and the metaphors embedded in the text' (cf. Iser 1978:150; Van der Merwe 2015b:5). This constitutes the attachment between a reader and, in this context, the biblical text. From the prayer, the following four images can be pointed out ${ }^{21}$ : 'bow my knees', the image of 'the Father', 'Christ dwelling in hearts' and 'rooted and grounded in love'.

The image of 'bow my knees': The reference, by implication, that the author is praying comes from the reference, 'I kneel before the Father' (3:14). This reference would have created expectancy in the reader. This expectancy engenders the reader's imagination that further engendered because of the verbs used, more expectation linked to the trinitarian God as the prayer was read: 'would grant', 'be strengthened', 'may dwell', 'being rooted and established', 'may be strong', 'to know' and 'may be filled' (O’Brien 1999:265).

A reason why the author describes the activity of prayer in terms of kneeling could be to generate more emotive experiential force to convey a greater intensity and feeling of supplication than the earlier reference to the author's praying in 1:16 (Lincoln 1990:202). According to Hendriksen and Kistemaker (2001:166), this specific posture epitomises 'humility, solemnity and adoration'. The author's reference that he dramatically 'bows his knees' before the Father prepares the readers for a particularly humble and aweinspiring prayer on their behalf (Heil 2007:150). In this prayer, the intercession and worship are obviously not mutually exclusive activities. It could well be that both references are combined here in Ephesians 3:14 to suggest an attitude of deep reverence for the Father, who is addressed in the love of the believer for God.

The image of 'the Father:' As a result of the impact of images on humans, images of God have a similar impact. A person's view of God influences that person's ideas and 'lived experiences' of God and that person's faith life in general. In fact, there will never be something like, the image of God in either theology or Christian spirituality. We all emphasise at times or in certain circumstances particular qualities of God when applicable.

20.Texts are linguistically polysemous: Texts should not be reduced to a singular linguistic meaning (cf Ricoeur 1973:97-111). Words are polyvalent and consequently generate 'various valid interpretations in different readers'. Today, intereters interpreters have an advan operative in contemporary interpretaton, help 307; Ricoeur 1976:43-44; Schneiders 2003:185).

21.Other images from the prayer refer to the believers as the 'whole family in heaven and earth', 'saints' and 'church'. 
Although the author could refer in his prayer to the image of God as Father ${ }^{22}$ to the first readers, they could never have exhausted the understanding of God (Perrin 2007:96). No single image or any description can describe this God fully. It is impossible to know God entirely, for God transcends all human intelligence and comprehension (Perrin 2007:97). ${ }^{23}$ What is said about God is not the issue. The issue is that what has been said about God and how it has been formulated, affects the God-world-human relationship. Most Christians perceive God as 'Father', 'Son' and 'Spirit'. Their basic point of departure is the perception of God as Trinity. This is the principal image of God in this prayer, in the Christian faith in general and Christian spirituality. 'Many different words are used to describe this Trinity and the individual persons of the Trinity' (p. 98).

The practical, everyday thinking about God and experiencing God had a huge impact in composing and shaping Christian spirituality as a way of life. What the Christian believer thinks about God - especially those dominant attributes that really quickly saturate the mind concerning God - influences that person's daily living - how they experience God in their everyday life. God as Father is one of these images. Believers in the early church address their daily prayers to God as Father. All these matters explicitly or implicitly influence believers to epitomise God (Perrin 2007:99).

In this prayer, the Being to whom the author bows down is referred to as Father. ${ }^{24}$ In antiquity, it was a word used to indicate intimacy and dignity and authority. ${ }^{25} \mathrm{~A}$ father pursued the good of his family or clan and loved them. The author regarded this God whom he approaches here in prayer as a loving and powerful divine Father. Earlier in this letter (2:18; cf. 3:12), the author has proclaimed that 'through Him [Christ] we both [believers] have our [their] access in one Spirit to the Father' (O'Brien 1999:255).

The beginning of any prayer with Father confesses a personal relationship with this God as it does to the lordship of God (Neufeld 2001:166). In this prayer, the reader becomes aware and imaginatively personally experiences the love of the Father. This is because of their relationship with Christ via the power of the Spirit.

The image of 'dwelling in hearts': In the third image, the author requests in this prayer (3:17) 'that Christ may dwell

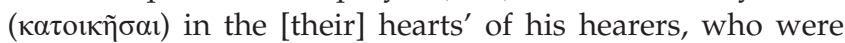
gentile believers. Through this request, he counters them to assemble with believing Jews. This he adds as a gift of the love of God (divine passive) because of their union of being

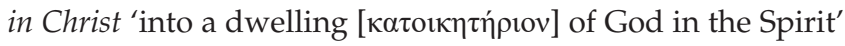

22. Metaphoric language occurs in all cultures (Lassen 1997:103). A major function is to '... provide a partial understanding of one kind of experience in terms of another kind of experience' (Lakoff \& Johnson 1980:154).

23.See from Ephesians 3:14-21 the following: 'surpasses knowledge' (3:19), 'who is able to do exceedingly abundantly above all that we ask or think' (3:20).

24.Other references in Ephesians to 'Father' (זатńр), 1:2, 3, 17; 2:18; 4:6; 5:20; 6:23.

25.Bending the knees is also, however, an expression of awe and reverence before God (e.g. Isa. 45:23; cf., Phlp. 2:10-11). Such a sense of awe is present here, in that prayer is directed to the God who is Father (Neufeld 2001:156).
(2:22). As a 'dwelling place' of God they stand in juxtaposition to the entire 'building' that, being fitted together by God, 'is growing into a holy temple in the Lord' (2:21). This temple's 'foundation' is 'built on the foundation of the apostles and prophets, Christ Jesus Himself being the corner stone' (2:20). Thus, the author is praying that Christ $^{26}$ who is united with believers, may now dwell and be experienced interiorly within the hearers' hearts through the Holy Spirit through which the love of God is present (cf. Heil 2007:153). This implies that they will be conscious of the presence of God's love, alerting and preparing them to experience the changing power of the Spirit and involvement of God in their everyday living.

The images of 'rooted and grounded' in love: In this last image, the author stresses the fundamental character that the love of God envisaged. Two closely linked metaphors are used, one botanical and the other architectural: 'rooted and grounded in love' (3:17). It certainly represents a mixed metaphor because roots would apply to a tree while foundation applies to a building. Both have the same connotation. The word order of the original ${ }^{27}$ stresses love, while the two perfect passive participles (in the nominative case) depict the notions of progress and the resulting state. For Bratcher and Nida (1993:86), it describes the condition of the readers. Love then becomes the soil in which believers are rooted and will grow. They will be built upon this

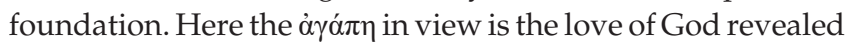
and experienced in Christ and poured into the hearts of people by the Spirit (cf. Rm 5:5, 8; 8:35-39). The 'lived experiences' of this divine love will transform the lives of believers.

The love of God then becomes experiential in the lives of believers, prompting them to love others and God and to experience God's involvement everyday as an act of his love. In this prayer, the author then notably anticipates the exhortations in the following chapters (cf. 4:2; 5:2). Those who are strengthened by the Spirit $(5: 18)$ and in whom Christ dwells will have their lives rooted and grounded in love (O'Brien 1999:260) and live according to the prescriptions referred to by the author in Chapters 4-6.

\section{Third mechanism: Entanglement in the text}

Waaijman (2002:742) asserted that readers construct the presentation of a sacred text in their imagination. This happens when they partake efficiently in the text's events. For Iser (1978:131), '[t]his involvement or entanglement, is what places us in the "presentness" of the text and what makes the text into a presence for us'. When a text is read (or studied), the reader is drawn into the text. The presence, experiences and involvement in the text depend primarily upon the reader's imagination and association with related and acquainted characters, objects and events in the text.

\footnotetext{
26. He is pointed out to be the "head stone' of the metaphorical "building' and 'dwelling place' that is the church. He is the 'head' over all things that God has given as a gift of God's love to the church, which is his 'body' (1:22-23).

27.The phrase, غ́v áyámn ('in love'), appears first.
} 
BOX 1: A chiastic expression of trinitarian experiences.

A Glory: He would grant you, according to the riches

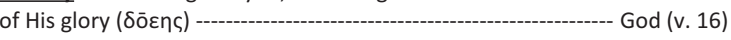

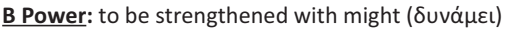

through His Spirit in the inner man ------------------------- Spirit (v. 16)

C Love: that you, being rooted and grounded in love

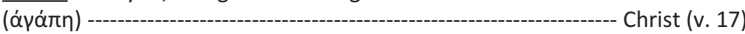

C' Love: to know the love (áyórn̨v) of Christ which

passes knowledge ---------------------------------------------- Christ (v. 19)

B' Power: according to the power ${ }^{1}(\delta$ úva $\mu \iota v)$ that

works in us ----- Spirit (v. 20)

A' Glory: to Him be glory ( $\delta$ ò $\alpha$ ) in the church ------------------ God (v. 21)

When they experience themselves being involved in the events in the text, such as 'to be strengthened with might through His Spirit in the inner man' (3:16), experiencing that Christ dwells 'in your hearts through faith' (3:17), following Jesus through walking in unity (4:1-6), being renewed in the spirit of their minds (4:23), then indeed something happens experientially to them (cf. Iser 1978:131).

Such text participation signifies that the contemplative reading of biblical texts can establish a variety of lived experiences, both divine and of the events in the text. The variety of spiritualities fostered by the reading of a text depends, firstly, on the content about the divine and, secondly, on who the reader is' (Van der Merwe 2015a:3).

\section{Experiencing the trinity through the chiastic structure in the text (see Box 1)}

When reading the text, the reader becomes aware of the interaction of the trilogy of 'glory', 'power' and 'love' expressed in this chiastic structure. This fostered the presence of God and the reader experiences the trinitarian God. The love of Christ (God) is experienced through the power of the Spirit. As a result of this event, the reader is first prepared (3:16) to experience the glory of God $(3: 21)$ through the love of Christ mediated by the Spirit. The implication will be that the readers will consequently experience 'all the fullness of God' (cf. Hendriksen \& Kistemaker 2001:171). According to the glory of God, the reader will be strengthened with power 'through His Spirit in the inner being' (3:16).

\section{Experiencing the trinity in the use of inclusive vocabulary}

The author draws the reader into the text with his use of the following inclusive vocabulary:

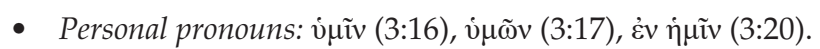

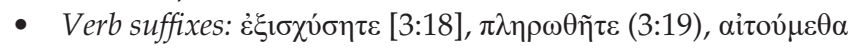
iे vooṽ $\mu \varepsilon v(3: 20)$.

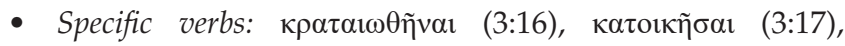

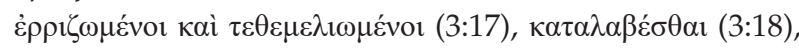
$\gamma v \tilde{o v \alpha i ́}(3: 19), \pi \lambda \eta \rho \omega \theta \tilde{\eta} \tau \varepsilon$ (3:19).

- Adjective plurals: $\pi \tilde{\alpha} \varsigma$, occurs with regard to 'saints' (3:18), 'requests' (3:20) and 'generations' (3:21).

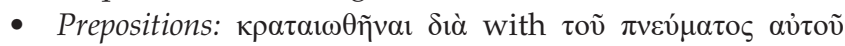

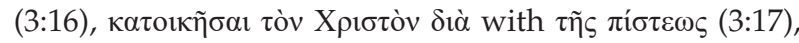

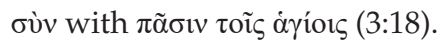

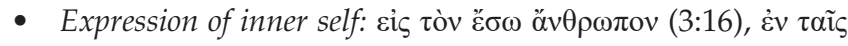

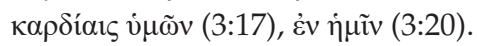

The author uses these, inclusive vocabulary, to draw the reader into the text to become part and to experience the love-related events described in the prayer. The following terminology has been selected for discussion because of space restrictions.

- Prepositions: The preposition, бóv (3:18), acts in this linguistic context as a marker of accompaniment and association: it involves the reader. 'Together with all the

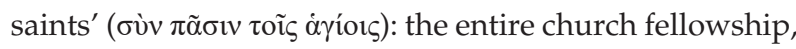
all the people of God, is the environment where this knowledge about God's love realise; it is not individually accomplished but is a 'corporate experience' (Bratcher \& Nida 1993:87-88).

- Personal pronouns: The author starts the prayer in the first

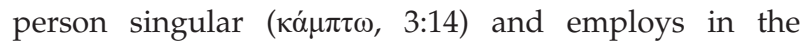
doxology in 3:20-21 the first-person plural (i் $\mu \tilde{v}, 3: 20$ ). This is his technique to draw the readers further into sharing his prayer's concerns - 'we ask or think' ( $\alpha i \tau o v ́ \mu \varepsilon \theta \alpha$ iे vooṽ $\mu \varepsilon v)$.

- Specific verbs: 'To be strengthened', (3:16); 'dwell in your hearts' (3:17) when the lives of people change; 'rooted and grounded in love' (3:17); 'to comprehend' (3:18-19); 'filled up to all the fulness' (3:19) - refer to the experience of God's love every day. The Greek verb for 'to be strengthened' $(\kappa \rho \alpha \tau \alpha \omega \theta \tilde{\eta} v \alpha l)$ is used in the passive voice 'to be made strong'. 'Although not formally expressed in Greek, the subject is 'you', 'for you to be made strong'. To give you power ... to be strong may be rendered as 'to cause you to be strong', because of God's love' (Bratcher \& Nida 1993:85).

- Expression of an inner 'lived experience': The phrase 'in your inner being' (3:16, NRSV) can be translated as 'in/ into the inner man'. This is virtually the same in meaning as in your hearts in the next verse (3:17) and in us in 3:20.

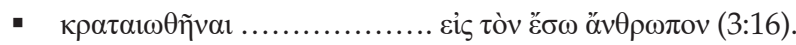

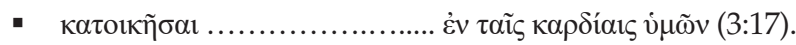

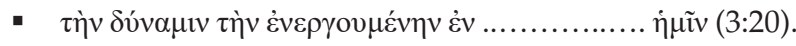

The readers need to be spiritually strengthened. The Spirit of God causes this to happen (cf. Bratcher \& Nida 1993:85; Lincoln 1990:215).

\section{Experiencing the trinity through the revelation of the love of God}

The pericope refers twice to love ( $\dot{\alpha} \gamma \alpha \dot{\pi} \pi \eta)$. In 3:17, it is used as a noun and refers to the most important quality or attribute of the Christian life. In 3:19, it is also used as a noun to refer to the love of Christ. No distinction between the Father's love, the Son's love or the believers' love is necessary. In the end, they affect one another. That is the effect of being in Christ. The result is that the love of God (2:4) finds expression in the love of Christ (2:13-18). This is 
the culmination of the mystery now revealed (Neufeld 2001:160-161)

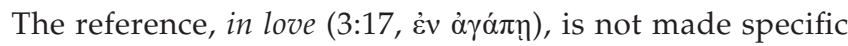
in this context by the author. Therefore, it may refer to love in all its aspects, which can then denote to mean love 'towards God and from God and towards fellow believers' (Bratcher \& Nida 1993:86). From the textual context, it seems probable to refer here in particular God's (or Christ's) love alone (3:18). From the perspective of $3: 19$,

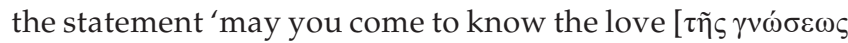

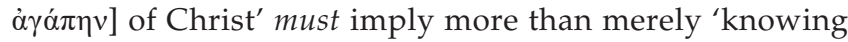
about his love'. The verb 'know' ( $\gamma v \tilde{\omega} v \alpha i, 3: 19)$ is often best translated as 'to experience'. Therefore, 'may you come to experience how he loves you' (Bratcher \& Nida 1993:88). This then implies the experience of God's love in everyday life.

\section{Experiencing the Holy Spirit in terms of the power of God}

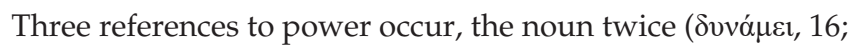

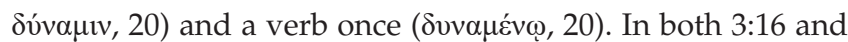
3:20, the noun refers to the strengthening of the inner person by the Spirit. This then relates to their relationship with God (Roberts 1983:91). The verb in 3:20 refers to the ability to do something.

The first request of the tripartite petition is that the church be empowered by God. This is extensively important in this prayer and the entire letter (so also Arnold 1989:137-9; Martin 1991:44; Schnackenburg 2001:150). This is so important because of the extent of the calling and task of the church. The church is to be 'His body, the fullness of Him who fills all in all' $(1: 23 ; 2: 16)$, 'one new humanity (2:15), 'a holy temple in the Lord' (2:21). Therefore, the author's concern for the empowerment of believers is the focus of his prayer (see also 1:15-23; 6:10-13). 'God is asked to empower the church with power' (Neufeld 2001:158) 'to know the love of Christ that surpasses knowledge' (3:19).

The second request is again expressed in 'power' vocabulary: 'that you may be able [strong enough,

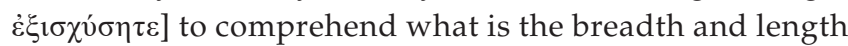
and height and depth' $(3: 18)$ of the love of Christ. The translation of the Greek verb $\kappa \alpha \tau \alpha \lambda \alpha \beta \varepsilon \delta \sigma \theta \alpha$ l (middle infinitive voice) as 'comprehend' is an adequate rendering. Many translations ${ }^{28}$ connect the four dimensions to the love of Christ. The immediately preceding reference to 'being rooted and grounded in love' (3:17) and the immediately following text, 'to know the love of Christ, which surpasses knowledge' (3:19), commend such an understanding. In the end, the love of God (2:4) comes to expression in the love of Christ (2:13-18). That is the

28.New American Bible; New International Version; Revised English Bible; Today's English Version. quintessence of the mystery now revealed (Neufeld 2001:160) and experienced.

Finally in the doxology ${ }^{29}$ of the prayer, the author deduces again the experience of the Spirit in his reference to power. Again, power is emphasised as an essential component of the preceding prayer report (3:14-19; cf. 1:15-23). The English terms dynamic and energy are reflected in the Greek in 3:20:

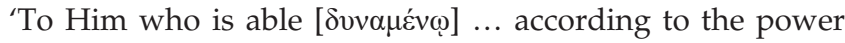

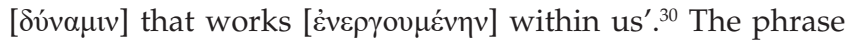
within us ( $\dot{\varepsilon} v \dot{\eta} \mu \tilde{i} v)$ is of particular importance because in 1:1920 the power of God is at work in Christ for the sake of believers (Neufeld 2001:161). That power that 'works within us' enables the believer to comprehend and experience the love of God in everyday life.

\section{Experiencing the love of God through cognition}

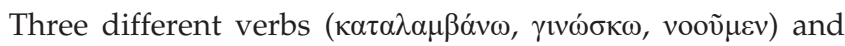
one noun $(\gamma \nu \tilde{\omega} \sigma 1 \zeta)$ have been used to refer to some cognitive processes during prayer: have been used to know ( $\gamma v \tilde{\omega} v \alpha i$,

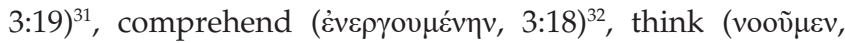

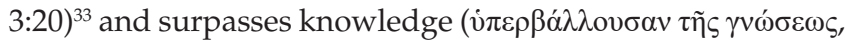
$3: 19)$. These are three different cognitive processes in the brain (know, comprehend and think).

In the end, the two verbs comprehending ( $\alpha \alpha \alpha \lambda \alpha \beta \varepsilon \dot{\varepsilon} \sigma \theta \alpha$ l, $18)^{34}$ and knowing ( $\gamma v \tilde{\omega} v \alpha i$, 19) ${ }^{35}$ are not intellectual exercises. Such knowing revolves around the reception of the gracious gift of the revelation of God's love. In addition, such knowing embraces the experience of Christ's love 'and a life and a mind nurtured by and built upon the exercise of such divine love. To know is to love' (cf. Neufeld 2001:161-162). Christian knowledge is always public and social. Such knowledge relates intimately to living out the love of Christ in the community (Barth 1974:394-395; Neufeld 2001:162).

As such comprehension (3:18) and knowing (3:19) can be accomplished only by those who are 'rooted and founded in love' (3:17). It is apparent that these cognitive references are not two activities that are merely mental. It is experiential knowledge, heart knowledge, which the author has in mind. According to 3:17, 'the heart' is the 'inner most part of the person' (Dunn 2003:74). This is the dwelling place of Christ through the Spirit in the believer (see also 3:16). Therefore, the heart influences all the 29. No reference to the Spirit occurs in the third request.

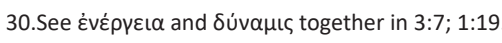

31.According to Arndt, Danker and Bauer, et al. (2000:200) 'to grasp the significance or meaning of someth [ing], understand, comprehend'.

32.According to Arndt et al. (2000:520), 'to process information, understand, grasp'.

33.According to Arndt et al. (2000:675), 'to form an idea about something, think, imagine'.

34.Arndt et al. (2000:199) 'To arrive at a knowledge of someone or something'. Louw and Nida (1996:II, 51), 'a know: 28.1; b learn: 27.2; c be familiar with: 27.18; d understand: 32.16; e acknowledge: 31.27 '.

35.Arndt et al. (2000:199) 'To arrive at a knowledge of someone or something'. 
activities of life - of a person's entire being, that is, 'all the "faculties" of heart and mind' (Hendriksen \& Kistemaker 2001:172-173).

\section{Fourth mechanism: Filling the gaps}

For Iser (1978:168), gaps occur in texts when only marginal information is communicated in the text. This then ordinarily promotes the reader to fill the gaps with 'imaginative juxtapositions'. This draws the reader into the reasoning in the text. The reader then consequently tries to fill the gap or to make sense with what is meant from what is not written. For Iser (1978:168), then the unsaid comes to life in the reader's imagination, so the said "expands" to take on greater significance than might have been supposed'.

In this prayer, the following phrases (superlatives) could have triggered the mind of the reader, what the author had in mind about God's love when referring to the following statements: 'riches of his glory' (3:16); 'to grasp how wide and long and high and deep is the love of Christ' (3:18); 'love that surpasses all knowledge' (3:19); 'be filled to the measure of all the fullness of God' (3:19) and 'to do immeasurably more than all we ask or imagine' (3:20).

Through these superlatives, the reader experiences the greatness and transcendent side of the love of the triune God.

\section{Riches of his glory (3:16)}

In the Greek text, this expression indicates the manner how God is requested to give. His provision ${ }^{36}$ should be juxtaposed to his glory or his magnificent richness. With this expression, the author requests God, who possesses so much abundance, that the blessings God provides may be according to his richness. In other words, the author asks that God in his answer to this prayer will exceedingly reveal the total immeasurability of God (Lincoln 1990:204) during God's involvement in the lives of believers.

The phrase 'the riches of (his) glory' is an important expression in the understanding of Christian spirituality. Lincoln (1990:204) referred to the other two occurrences in the Pauline epistles: in Romans 9:23 (cf. also Phlp 4:19) and in the pseudo-Pauline epistle, Colossians 1:27. According to this phrase, in its various contexts, the noun $\delta$ ó $\xi \alpha$ (glory) can be regarded as synonymous with power. In Romans 6:4, Paul writes that 'Christ was raised from the dead through the glory of the Father', and in Colossians 1:11, the author asks that the Colossians be 'strengthened with all power, according to His glorious might'. The preposition кató (according to) indicates in Ephesians 3:20 the norm or measure of God's giving. 'In this way, the writer's formulation of his request is meant to evoke the confidence of the readers in God's ability to grant what is asked in a fashion more than adequate for their needs' (Lincoln 1990:204).

36. Refers in this context to all daily needs (physical, non-physical and spiritual), implied by the references: 'the riches of his glory' (3:16), 'filled with all the fullness implied by the references: 'the riches of his glory' $(3: 16)$, 'filled with all the fullness
of God' (3:19) and 'to do exceedingly abundantly above all that we ask or think, of God' (3:19) and 'to do exceedingly abundan
according to the power that works in us' (3:20).
To grasp how wide and long and high and deep is the love of Christ (3:18)

Lincoln (1990:208-213) discusses this statement in detail how several other scholars interpreted it and how this reference was used in antiquity. The expression, 'what is the breadth and length and height and depth' (3:18), functions as the single object that is to be comprehended, comprising four words that form a pair of rhetorical merisms, that is, opposites to express totality. The first merism, absolute 'breadth and length', refers to the opposite dimensions of horizontal space. The second merism, 'height and depth' refers to the opposite dimensions of vertical space taken together as a merism. The combination of these opposites emphasises the dimensions of the immense love of God.

The love of Christ is so overwhelming that its extent will never be measured and never be comprehended by the human mind. This expresses the 'ultimate mystery about the divine intervention [lived experiences of God] of which Christ's love is the manifestation' (Lincoln 1990:213).

\section{Love that surpasses all knowledge (3:19)}

That any audience is paradoxical 'to know the love of Christ which surpasses knowledge' (3:19) emphasises how the knowledge and experience of God's love transcend human knowledge and experience. Therefore, this love can only be given as a gift of the love of God (Heil 2007:157). Although this knowledge implies personal knowledge, it includes discernment of the magnitude of the love of God in God's redemption plan. Therefore, a reduction of the love of God to a level of simply intellectual reflection is unacceptable. The author wants his readers to perceive the dimensions of God's love in their personal experiences (O'Brien 1999:264). Paradoxically, the request is that they may 'know the love of Christ, which surpasses knowledge' (3:19). The former expression, 'what is the breadth and length and height and depth', focused on the measureless dimensions of Christ's love. Now, the author endeavours to express the incomprehensibility of Christ's love (O'Brien 1999:264) in the phrase, 'love that surpasses all knowledge' (3:19).

\section{Fullness of God (3:19; also cf. 1:23; 4:10)}

The will expressed in 3:19 that believers are to 'be filled up to all the fullness of God' (3:19) preserves the element of growth and development, visible also in 4:13. The church should be regarded to be in a constant need of being filled towards all the fullness of God. 'The element of direction and process must not be obscured in this text' (Neufeld 2001:162). The transformation process, the experience of growth in things such as knowledge, love, joy, etc. will not cease (Hendriksen \& Kistemaker 2001:174).

As believers are 'strengthened with power through His Spirit in the inner being (3:16), as they allow 'Christ to dwell in [their] hearts through faith' and as they 'know [more] of the love of Christ', so the process 'may be filled up to all the 
fullness [of the life and power] of God will materialise.' Response to the imperative of 5:18, 'be filled with the Spirit', will also be part of the realisation of this process (Lincoln 1990:215).

Note should be taken that the phrase, 'that you may be filled', follows immediately after the phrase, 'to know the love of Christ' (3:19). According to this sequence, it can be deduced to introduce the last statement of verse 19 to, 'by experiencing his love you can be completely filled ...' (cf. Bratcher \& Nida 1993:88). This is not only to be understood within the framework of spiritual growing but also in God's involvement in every aspect of the everyday life of believers that concerns the full indwelling and empowerment of God.

\section{To do immeasurably more than all we ask or imagine $(3: 20)$}

The subject of 3:21 is the glory, directed to God in the prayer. It is the worship and praise of those redeemed for the redemption of mankind. God, to whom this glory is offered, is designated as one 'who is able to do exceedingly abundantly above all that we ask or think' (NKJV, Bratcher \& Nida 1993:88). These words certainly would have encouraged the early readers, granted them hope and strengthened their faith.

The force of the author's rhetoric can be experienced in the build-up of the thought exposed by his language. He refers to

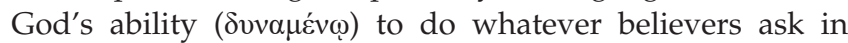
prayer. 'God is able to do far more abundantly beyond all

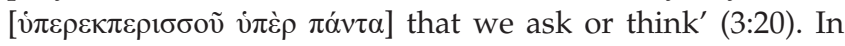
fact, 'this inexpressible power is at work within us' (3:20; Lincoln 1990:216; also, Bratcher \& Nida 1993:89) and obviously because of his love for those who believe in God.

This reference to the mighty deeds of God dominates in Chapters 1-3. All the requests in these chapters are based on this reference to God's mighty deeds. These deeds relate to both God's mystery and transcendence for this God can do immeasurably more than what anyone can ask or imagine. ${ }^{37}$ The human mind cannot grasp this (Roberts 1983:99).

Through these superlatives, the reader experiences the greatness and transcendent side of the love of the triune God continuously in everyday living.

\section{Conclusion}

From this investigation, the following aspects can be pointed out featuring in the hearing or reading of this (intercessory) prayer:

- In this article, the 'hermeneutic research approach' of Kees Waaijman has been applied on the prayer in Ephesians 3:14-21 to explore how the reading or hearing of biblical texts can foster experiences of the trinity (see

37. See Poythress (2020:190-196) on the mystery of God. According to him "The Father is God, not a part of God. The Father manifests in himself the whole of what God is. He has all of God's attributes, including simplicity. And so, it is with the Son The Son is God, fully God. The Holy Spirit is God. This is a mystery. We cannot The Son is God, fully God. The Holy Spirit is God. This is a mystery. We cannot
comprehend it because God alone is God and we are not. Nothing in the created comprehend it because God alone is God
world offers a full model for the Trinity'. also Schneiders 1986, 2016). The 'lived experiences' of biblical texts moreover prepare readers for experiencing the trinitarian God in everyday life with the effect of selftranscendence to live according to the divine experience.

- The article has pointed out how the divine attribute of love features among the three divine persons in cooperation. It became evident how the trinity concept can feature in prayer and foster lived experiences according to Ephesians 3:14-21. The research also succeeded in identifying conceived spiritualties (lived experiences of the divine trinity), which the hearers (readers) could have perceived and experienced when hearing this prayer or even praying a similar prayer themselves.

- We might ask the question whether the prayer of 3:14-21 was also meant to teach the church how to pray especially considering its identity and task: with boldness and confidence the church must request God for power, knowledge, especially love, to experience the fullness of God during everyday living.

- It became evident how imagination can play a crucial role to stimulate faith, hope (expectation) and love among believers. This is verified from the high number of superlatives used by the author.

Prayer should always have a trinitarian slant, with love as the most fundamental attribute of God always featuring. This should lead to the glorification of God (3:21). Prayer should direct those who pray regularly to experience for themselves the mutual interacting power, involvement and love of this trinitarian divine being in everyday life of divine: salvation, protection, guidance, healings, combatting of evil, happiness, etc.

\section{Acknowledgements Competing interests}

The author declares that he has no financial or personal relationships that may have inappropriately influenced him in writing this article.

\section{Author's contributions}

D.G.V.D.M. is the sole author of this article.

\section{Ethical considerations}

This article followed all ethical standards of research without direct contact with human or animal subjects.

\section{Funding information}

This research received no specific grant from any funding agency in the public, commercial or not-for-profit sectors.

\section{Data availability}

Data sharing is not applicable to this article as no new data were created or analysed in this study. 


\section{Disclaimer}

The views and opinions expressed in this article are those of the author and do not necessarily reflect the official policy or position of any affiliated agency of the author.

\section{References}

Arndt, W., Danker, F.W. \& Bauer, W., 2000, A Greek-English lexicon of the New Testament and other early Christian literature, 3rd edn., University of Chicago Press, Chicago, IL.

Arnold, C.E., 1989, Ephesians: Power and magic: The concept of power in Ephesians in light of its historical setting, SNTS MS, 63, Cambridge University Press, Cambridge.

Barth, M., 1974, Ephesians: Introduction, translation, and commentary on chapters 1-3, Anchor Bible, vol. 34, Yale University Press, New Haven, CT.

Barth, K., 2009, The doctrine of God, § 28-30, Church Dogmatics, vol. II, ed W.W. Bromile \& T.F. Torrance, T\&T Clark, London.

Barton, S.C., 2006, The spirituality of the gospels, Wipf \& Stock Publisher, Eugene, OR. Baugh, S.M., 2016, Ephesians, Lexham Press, Bellingham.

Bratcher, R.G. \& Nida, E.A., 1993, A handbook on Paul's letter to the Ephesians, United Bible Societies, New York, NY

Brümmer, V., 2005, Atonement, Christology and the trinity. Making sense of Christian doctrine, Ashgate Publishing Limited, Hampshire.

Brümmer, V., 2010, 'Spirituality and the hermeneutics of faith', HTS Teologiese Studies / Theological Studies 66(1), 1-5. https://doi.org/10.4102/hts.v66i1.891

Carter, J., 2014, ' 9 things you should know about prayers in the Bible', Bible \& Theology, viewed 25 March 2021, from https://www.thegospelcoalition.org/ article/9-things-you-should-know-about-prayer-in-the-bible/.

Daniels, C., 2014, The trinity in Ephesians, Redeemer Church, viewed 14 February 2021, from https://redeemerchurch.wordpress.com/2014/02/08/the-trinity-inephesians/.

Dunn, J.D.G., 2003, The theology of Paul the Apostle, T\&T Clark, London

Dünzl, F., 2007, A brief history of the doctrine of the Trinity in the early church, T \& T Clark, London.

Emery, G., 2011, The Trinity: An introduction to Catholic Doctrine on the Triune God (Thomistic Resourcement Series), Catholic University of America, Washington, DC.

Emery, G., Levering, M. \& Cessario, R., 2012, The Oxford handbook of the trinity, Oxford University Press, Oxford.

Fee, G.D., 1994, God's empowering presence: The holy spirit in the letters of Paul, Hendrickson, Peabody, MA.

Gadamer, H.G., 1975, Truth and method, Sheed \& Ward, London.

Heil, J.P., 2007, Ephesians: Empowerment to walk in love for the unity of all in Christ, Society of Biblical Literature, Atlanta, GA.

Hendriksen, W. \& Kistemaker, S.J. 2001, Exposition of Ephesians, Baker Book House, Grand Rapids, MI.

Holmes, S.R., 2012, The quest for the trinity: The doctrine of God in scripture, history and modernity, InterVarsity Press, Downers Grove, IL.

Iser, W., 1978, The act of reading. A theory of aesthetic response, John Hopkins University Press, Baltimore, MD.

Johnson, W.S., 1997, The mystery of God: Karl Barth and the postmodern foundations of theology, Columbia Series in Reformed Theology, John Knox Press, Westminster.

Jones, T., 2002, 'The promise and challenge of Trinitarian spirituality', Sewanee Theological Review 46(1), 77-91.

Jüngel, E., 2002, Entsprechungen: Gott-Wahrheid-Mensch (Theologische Erörterungen), Mohr Siebeck, Tübingen.
Kim, S.S., 2017, The spirituality of following Jesus in John's Gospel, Pickwick Publications, Eugene, OR.

Kroll, W., 2007, Ephesians. Life in God's family, Crossway Books, Wheaton, IL.

Lakoff, G. \& Johnson, M. 1980, Metaphors we live by, Chicago University Press, Chicago, IL.

Lassen, E.M., 1997, 'The Roman family: Ideal and metaphor', in M. Moxnes (ed.), Constructing early Christian families: Family as social reality and metaphor pp. 103-120, Routledge, Chicago, IL. https://doi.org/10.4324/9780203440490

Letham, R., 2004, The Holy Trinity: In scripture, history, theology, and worship, Presbyterian \& Reformed Publishing Company, Phillipsburg.

Lincoln, A.T., 1990, Ephesians, Word Incorporated, Dallas, TX.

Louw, J.P. \& Nida, E.A., 1996, Greek-English lexicon of the New Testament: Based on semantic domains, United Bible Societies, New York, NY.

Martin, E.D., 1991, Ephesians, Colossians, and Philemon, Interpretation, John Knox, Atlanta, GA.

Mccall, T. \& Rea, M., 2010, Philosophical and Theological essays on the Trinity, Oxford University Press, Oxford.

Neufeld, T.R.Y., 2001, Ephesians, Herald Press, Scottdale.

O'Brien, P.T., 1999, The letter to the Ephesians, W.B. Eerdmans, Grand Rapids, MI.

Perrin, D.B., 2007, Studying Christian spirituality, Routledge, New York, NY.

Phan, P.C., 2011, The Cambridge companion to the trinity (Cambridge Companions to Religion), Cambridge University Press, Cambridge.

Poythress, V.S., 2020, The mystery of the trinity. A trinitarian approach to the attributes of God, P\&R Publishing Company, Phillipsburg, NJ.

Ricoeur, P., 1973, 'Creativity in language: Word, polysemy, metaphor', Philosophy Today 17(1), 97-111. https://doi.org/10.5840/philtoday197317231

Ricoeur, P., 1976, Interpretation theory: Discourse and the surplus of meaning, Christian University Press, Fort Worth, TX.

Roberts, M.D., 1983, Ephesians, Zondervan, Grand Rapids, MI.

Scheldrake, P., 2000, 'What is spirituality?', in K.J. Collins (ed.), Exploring Christian spirituality, pp. 21-42, Baker Books, Grand Rapids, MI.

Schnackenburg, R., 2001, Epistle to the Ephesians: A commentary, T\&T Clark, Edinburgh.

Schneiders, S.M., 1986, 'Theology and spirituality. Strangers, rivals or partners', Horizons 13(2), 253-274. https://doi.org/10.1017/S036096690003632X

Schneiders, S.M., 2003, Written that you may believe. Encountering Jesus in the Fourth Gospel, Crossroad Publishing Company, New York, NY

Schneiders, S.M., 2016, 'Biblical spirituality', Interpretation: A Journal of Bible and Theology 70(4), 417-430. https://doi.org/10.1177/0020964316655108

Sonderegger, C., 2020, The doctrine of the Holy Trinity: Processions and persons (Systematic Theology, Vol 2), Fortress Press, Minneapolis, MN.

Van der Merwe, D.G., 2014, 'Eenheid as matriks van die spiritualiteit van die Evangelie volgens Johannes', Litnet Akademies 11(1), 372-400.

Van der Merwe, D.G., 2015a, '1 John: "Effects" in biblical texts that constitute "lived experiences" in the contemplative reading of those texts', In die Skriflig 49(2), 1-9. https://doi.org/10.4102/ids.v49i2.1930

Van der Merwe, D.G., 2015b, 'Divine fellowship in the Gospel of John: A trinitarian spirituality', HTS Teologiese Studies / Theological Studies 75(1), 1-12. https://doi. org/10.4102/HTS.V75i1.5375

Van der Merwe, D.G., 2019, 'The divinity of Jesus in the Gospel of John: The "lived experiences" it fostered when the text was read', HTS Teologiese Studies Theological Studies 75(1), 1-13. https://doi.org/10.4102/htsv.75i1.5411

Venter, R., 2015, 'A Trinitarian approach to spirituality: Exploring the possibilities', HTS Teologiese Studies / Theological Studies 71(1), 1-10. https://doi.org/10.4102/HTS V7111.2952

Waaijman, K., 2002. Spirituality: Forms, foundations, methods, transl. J. Vriend, Peeters, Dudley. 